\title{
THE ACTIVITIES OF LOCAL GOVERNMENTS IN THE REVITALIZATION OF PUBLIC SPACE IN BULGARIA AND POLAND
}

\author{
Ivo Kostov, PhD \\ Department of Economics and Management of Construction \\ Faculty of Economics \\ University of Economics - Varna (Bulgaria) \\ e-mail:i.kostov@ue-varna.bg \\ Sławomir Palicki, PhD \\ Department of Spatial and Environmental Economics \\ Faculty of Management \\ Poznań University of Economics and Business \\ e-mail: Slawomir.Palicki@ue.poznan.pl \\ Izabela Rącka, PhD \\ Department of Management and Public Law \\ Faculty of Social Sciences and Humanities \\ The President Stanistaw Wojciechowski State University of Applied Sciences in Kalisz \\ e-mail:i.racka@pwsz.kalisz.pl
}

\begin{abstract}
The research discussed in the article focuses on public space in urban areas and revitalization activities carried out by local governments. The goals of the paper are to identify the conditions and opportunities for the development of public space by local governments of Bulgaria and Poland, to find regularities (similarities and differences) and to assess the actions taken. The specific objective is to illustrate the process of planning and managing selected large revitalization investments in urban public spaces in Bulgaria and Poland. The research methods used comprise the analysis of literature, including official documents and acts of law and case studies.

The paper analyzes the conditions and manifestations of activities taken by local governments regarding investment in public space (development and revitalization of public space programs and investing in real estate) in Bulgaria and Poland, using examples from selected cities. The authors selected two comparable urban areas: Varna in Bulgaria and Poznań in Poland, chosen intentionally due to the similarity of the two post-socialist bloc countries and the availability of information. Bulgarian and Polish state law and various acts of local law were analyzed. The experimental part of the publication introduces case studies of investments in the revitalization of real estate in public space managed by the local governments. It shows examples of projects which are relevant to the development of the cities under study.
\end{abstract}

Key words: revitalization, public spaces, local government expenditures, localities policy, municipality.

JEL Classification: O18, R19, R53.

Citation: Kostov I., Palicki S., Rącka I., 2017, The Activities of Local Governments in the Revitalization of Public Space in Bulgaria and Poland, Real Estate Management and Valuation, vol. 25, no. 1, pp. 103-111.

DOI: $10.1515 /$ remav-2017-0007 


\section{Introduction}

Investment in public space as well as its revitalization by local governments are essential factors of real estate management. Municipal real estate management must go beyond basic estate management such as sales, leases or renovations. It should be integrated with the local development plans and, thus, comprise holistic activities aiming to improve how buildings interact with their surroundings and help them create positive relationships with the environment.

Local governments decide on the type of activities (active, passive) and direction taken by the commune (municipal unit), which is both the owner of the public real estate and the manager of the space (including privately owned space). Regardless of the developmental strategy chosen by the local government, any individual investment and any activities aiming to encourage private investments must consider information regarding their usefulness (including recognizing human interactions and predicting meeting areas) (POIESI, CAVALLARO 2015) and effects (including non-economic effects) of such investments.

\section{Literature review: revitalization of public spaces}

Revitalization is a coordinated process, carried out by the local government together with the local community and other participants. It constitutes a part of the development policy, aiming to prevent the degradation of urban space and avoid crisis situations, stimulate development and positive change through an increase in social and economic activity, improve the residential environment and protect national heritage in accordance with the principles of balanced development (ZIOBROWSKI 2010).

Revitalization can be accurately described as a collection of sequential activities leading to invigoration and permanent improvement in the condition of degraded urban areas and to solving the problems associated with these areas. This is done in keeping with the idea of raising the standard of living for local communities (PALICKI 2007, p. 190).

Admittedly, central areas do not require strong incentives for residents and other space users to enjoy them; however, they still need to provide opportunities to do so. Therefore, it is important that public space is well looked after, aesthetically acceptable and usable (with appropriate legal status). Putting too many constraints on the potential space users - residents, businesses, workers, clients, visitors - lowers their desire to make use of the space (Jak przetworzyć... 2015).

The first revitalization projects were delivered in Poland as early as the beginning of the 1990s (for example the project of the "City Renewal Act") and later other mechanisms supporting revitalization activities became available, such as: the Public-Private Partnership Act and EU programs: IROP, Wielkoposka ROP, PHARE, and JESSICA. Often, revitalization processes are carried out in areas of public space such as streets, markets, parks or squares.

Some say that public space is what makes a city. Accordingly, it constitutes a subject of interdisciplinary research in sociology, geography, political science, anthropology, planning, architecture, design and philosophy. However, it was not until 1990, when public space began to disappear, that the subject sparked renewed interest among researchers (BODNAR 2015).

Public space is often perceived differently by various authors:

- the public space of a city (anthropogenic) is an integrated space of various assets and values (urban-architectural, social and economic) serving to satisfy the various needs and aspirations of an urban community whilst validating its spatial and social appeal (CICHY-PAZDER 2008),

- the public space of a city (...) is a space of social communication which is connected with the functionally chosen section of the city (NOWAK 2008),

- public space (urban) is one which creates opportunities and encourages direct interaction between individuals and social groups (CICHY-PAZDER 2008).

The use of public space brings about external effects, both positive and negative. They are the consequence of the production or consumption of certain goods, which are not part of the individual budget of the entity which produces or consumes this good, but which, nevertheless, positively or negatively influence the common budget (profits or costs affect the whole society, most often indirectly) (REKOWSKI 2011). It is worth remembering that, in cases of well-managed public space, external effects associated with public goods are mostly beneficial and "(...) contribute to improvements in the functioning of the city (...), and simplify the life of the residents and the operation of local businesses. For city users, these benefits are cost-free or partially free. Their functioning is, therefore, cheaper and consequently more competitive in the general market," (CZORNIK 2004). 
Revitalization of public space may have various consequences. Commonly, literature points to gentrification as a negative side effect of revitalization (SMITH 1987, VAN CRIEKINGEN, DECROLY 2003, COLLET 2012, ZHENG, KAHN 2013). Another significant issue regarding investment in public space is the possibility of using it for purposes different than those for which it was originally designed: TOOLIS and HAMMACK (2015) mention the problem of the homeless taking over revitalized public space. In the context of "privatization" or public space being managed by private entities, such a situation leads to the introduction of mechanisms restricting the freedom of access to public space.

\section{Data and Methods}

On the local level, real estate management is a set of activities carried out, in accordance with the law, by the authorities of municipal units, aimed at maintaining the real estate located within the municipal unit in a suitable and optimal condition. The research methods used to investigate the problem of the local government's investment in public spaces comprise: the analysis of official documents and acts of law, and case studies.

The basic legal documents related to the management and overall development of municipal property in Bulgaria and, in particular, that of Varna Municipality are: the Municipal Property Act, the Ordinance on the Acquisition, Management and Disposal of Municipal Assets; 2011-2015 Municipal Property Management Strategy (for Varna Municipality); Varna Municipality Budget; and annual programs for the management and disposition of municipal properties. The study of these acts aims to outline conclusions and form guidelines for the development of the territory of the municipal unit, which is directly related to the community's lifestyle and perspectives.

The Municipal Property Act regulates issues on the acquisition, management and disposal of property and chattels constituting municipal property. In the analyzed country, municipal property is public and private domain. Public domain property is: real property and chattels as determined by law, real property assigned for the performance of functions of local government authorities and local administration, and other real property assigned for the long-term meeting of public needs of local importance as identified by the municipal council. Private domain property is:

- local roads, streets, squares, public parking lots and green areas,

- municipal housing assigned for administrative, health, educational, cultural and sports uses,

- grids and facilities of technical, transportation, communication and engineering safety structures servicing the territory of the municipality,

- water bodies, and water facilities and systems,

- municipal forests.

All other municipal real property and chattels shall be deemed private municipal property. The products and revenues from real property and chattels in municipal public domain ownership shall also be the private property of the municipality. The following types of assets can be considered private municipal property: municipal buildings, land and zoned land properties, municipal housing, workshops and garages, and municipal agricultural land.

Provided that given real property and chattels constituting municipal property cease to have the uses described above, they are declared by the Municipal Council private municipal property, and vice versa. These two types of property have certain characteristics, namely:

- public municipal property cannot be acquired under a statute of limitation, cannot be expropriated nor transferred into third-party ownership, and shall not be subject to restitution,

- real property and chattels in municipal private domain ownership can be the subject of disposal as the general provisions with regard to ownership shall apply to them unless otherwise provided for in an act.

The municipal council shall adopt, for its four-year term in office, a municipal property management strategy. This strategy shall determine the policy of development of the municipal property and the economic activities of the municipality, and shall contain:

- the basic goals, principles and priorities in the acquisition, management and disposal of real property in municipal ownership,

- the basic characteristics of the different types of real property which can be leased out or disposed of,

- the municipality's need for new real property and the capabilities for its acquisition; other information indicated by the municipal council. 
To implement the strategy, the municipal council shall adopt (prior to the adoption of the annual municipal budget) an annual municipal real property management and disposal program, which may be updated over the course of the year. The program contains:

- a forecast of expected income and requisite expenses related to the acquisition, management and disposal of real property in municipal ownership,

- a description of the real property which the municipality intends to set out to be leased, sold, pass on as a contribution in-kind to the capital of companies, used for setting up of liens, or granted on concession, exchanged for property of individuals or legal entities (including a detailed description of the needs and type of the real property which the municipality wishes to acquire in return); the real property which the municipality intends to acquire, and the relevant acquisition methods,

- facilities for the construction of which the expropriation of private properties is required.

Built-up property in municipal public domain ownership must be insured, including insurance covering natural disasters and earthquakes. Some real properties and chattels in municipal private domain ownership must also be insured, as determined by the respective procedure.

To implement the activities set forth above, units for the performance of the functions and tasks under the Municipal Property Act shall be set up within the structure of municipal administration.

In Poland, the legislative act regarding real estate management is the Polish Real Estate Management Act (1997). Some of the main objectives of real estate management are managing the real estate of the State Treasury, communes, districts and provinces, as well as spatial policy. The implementation of the individual tasks of a commune is made possible by the use of the following tools (TROJANEK 2014):

- direct: real estate turnover, transfer to permanent administration, conversion into perpetual usufruct, differentiation of rates for the above deeds and of real estate tax, application of betterment levies and re-zoning fees,

- indirect: shaping the field of supply and demand in the real estate market; exerting an influence through planning, financial and tax initiatives; land investment.

Appropriate municipal real estate management requires the drafting of an asset status and estate management strategy (municipal strategic plan) as well as the preparation of the conditions and directions of the spatial development plan and (non-compulsory) local spatial development plans.

An essential aspect of real estate management is the maintenance of spatial order, which comprises various elements of life (e.g. social, cultural, economic, aesthetic and ecologic order) (ŹRÓBEKRÓŻAŃSKA 2011, p. 41). If the spatial policy of a given commune is run actively, it may encourage local development by stimulation of the private sector (TROJANEK 2015). One of the investment types undertaken by both a commune and the private sector are activities relating to the revitalization of public space. Incidentally, due to the lack of adequate public funding enabling investment in public space, cooperation with private (commercial) entities is often indispensable (BELNIAK 2008, WOJEWNIKFILIPKOWSKA 2012).

In the case of Poznan, the key documents which constitute the legal base for real estate management activities, including the management of residential resources, comprise:

- the Poznan City Council Resolution of 13 October 2009 regarding the principles for real estate management in the city of Poznań. The resolution establishes the rules for managing the city's real estate regarding purchasing, sale and mortgaging, as well as leasing and renting for a fixed term of 3 years and over or for a non-fixed term. It also regulates lease and rental contracts entered in on the same property after the fixed-term contract of up to 3 years has expired,

- the Poznan City Council Resolution of 13 October 2009 regarding rental agreements for housing owned by the Poznan City Council. The resolution governs rental agreements for housing owned by the council and regulates the course of action for meeting the residential needs of members of the Poznań self-governed community,

- the City of Poznań residential policy for the years 2012-2022 (prepared by: Instytut Gospodarki Nieruchomościami [IGN, Institute for Real Estate Management], 2012). Additionally, research is currently being carried out in Poznan and the surrounding communes in view of preparing a new residential policy, taking into account the requirements for balanced spatial and population development, 
- the Poznan City Council Resolution of 10 December 2013 regarding the Strategic Development Plan for the City of Poznań until 2030. The resolution approves the Strategic Development Plan for the City of Poznań until 2030 (amended 2013).

\section{Empirical Results}

\subsection{Revitalization of public spaces in Varna (Bulgaria)}

In connection with current Bulgarian legislation, a 2011-2015 Municipal Property Management Strategy was prepared for Varna Municipality which continues the development of the region that had been taking place for the past 12 years.

Municipal property management must be understood as an integrated process successfully adapted to new economic conditions, including systematic and coordinated activities and practices through which Varna Municipality uses its property and manages the risks, costs and revenues of its property wisely throughout the entire life cycle of the property, i.e. acquisition, use, maintenance, protection and disposal, to achieve the set/identified goals.

On the other hand, the management and disposal of the municipal property of Varna Municipality is an organized and dynamically operating system, comprising a set of principles, rules, regulations, mechanisms and approaches, as well as forms of citizen participation in local government.

The Master Plan, ratified by the state authorities of the Republic of Bulgaria and constituting a powerful tool for creating future investment processes, plays a major role in the strategy of Varna Municipality.

In pursuance of Article 4, Para 5 of Ordinance No. 7 of 22 December 2003 on the rules and regulations for the zoning of types of individual areas and zoned areas, with master plans of cities and their lands (or parts thereof) and of settlements of national importance, the overall (predominant) use of a number of land properties with similar characteristics, grouped into areas and territories, is determined.

The following are the priorities for municipal property management of Varna Municipality:

- acquiring municipal property to meet the needs of public services,

- effective property management,

- maintaining municipal properties according to established standards,

- preservation of existing municipal property seen as a strategic resource for the development of the municipality.

Some of the following key points are among the objectives of municipal property management:

- municipal property development,

- implementation of private/public partnerships,

- development and modernization of technical infrastructure.

A project named Aesthetics and Modernization of the Main Pedestrian Areas and Public Recreation Areas of the City aims to achieve the following goal: improving the physical and living environment in the municipal center (the city of Varna) as a prerequisite for ensuring a sustainable and ecological urban environment with high quality of life and sustainable socio-economic development.

The specific objective of the project was to improve the status and attractiveness of the urban environment in the municipal center (the city of Varna), which included:

- aesthetization and modernization of the main pedestrian zones and public recreation areas,

- increasing the accessibility of the city center, including creating an accessible architectural environment for the disabled,

- creation of conditions for the integration of disadvantaged groups,

- increasing the safety and security of the urban environment.

The project provided a comprehensive reconstruction and modernization of the pedestrian zone of Varna. Its aim was to unite the historically developed fragments of the area into the urban fabric, full of useful and interesting information, clear and easy to follow routes and pleasant aesthetics. It gave a unified concept of a safe, sustainable and high environmental and aesthetic quality urban environment - pedestrian pavements, cycle paths, color design and artistic lighting, appropriate elements of urban design - small architectural forms, signposting, efficient street lighting, various forms of urban landscaping, building a comprehensive irrigation system and creating an accessible architectural environment. 
The municipality of Varna decided the project will cover the entirety of routes of the main pedestrian zone of the city which are as follows:

- City Garden, Independence Square, Knyaz Boris I Blvd, Ruse str.

- Slivnitsa Blvd in scope Knyaz Boris I Blvd - Petko Karavelov str. - Stefan Karadzha str. Slavyanska str. - Primorski Blvd,

- Mitropolit Simeon Square,

- Preslav str. within Knyaz Boris I Blvd - Han Asparuh str. - Odesos str.,

- San Stefano str. in scope Odesos str. - Graf Ignatiev str. - Primorski Blvd,

- Slivnitsa Blvd - area "Sevastopol".
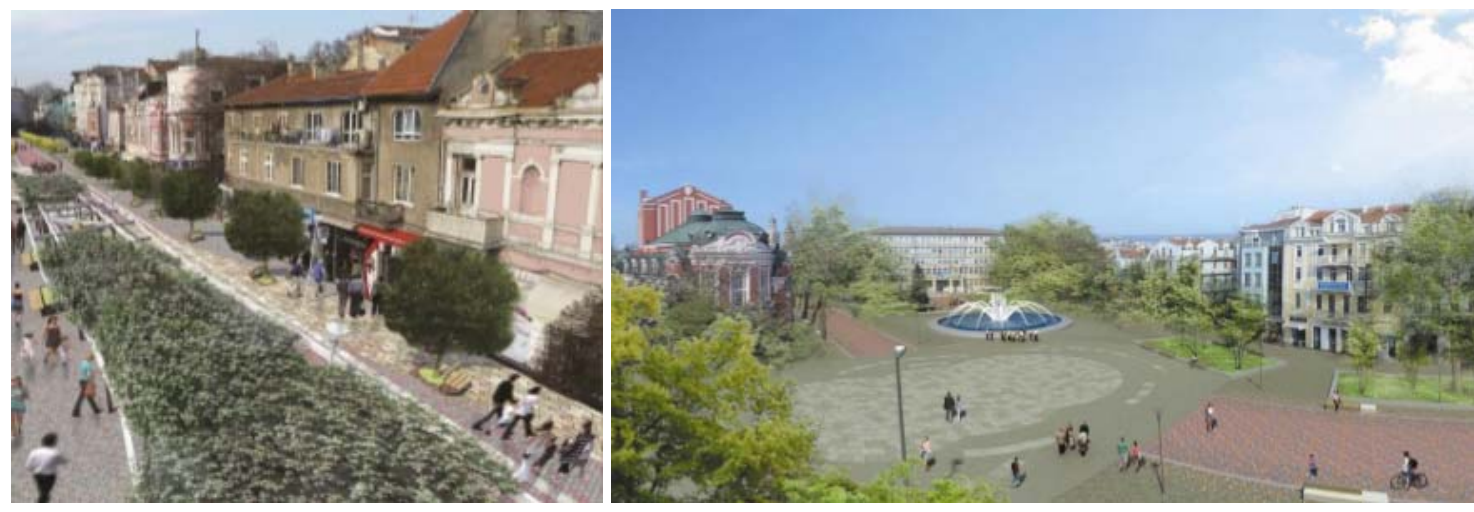

Fig. 1. Knyaz Boris I Blvd and City Garden, Varna. Source: Проект № Bg161po001-1.4.09-0006 „Естетизация И Модернизация На Главни Пешеходни Зони И Зони За Обществен Отдих На Град Варна“

Total project size constituted BGN 9,278,247.39, distributed as follows:

- BGN 7,407,196.76, constituting $85 \%$ of the total costs of the project co-financed by the ERDF,

- BGN 871,434.91, constituting $10 \%$ of the total project costs financed by the national budget,

- BGN 435,717.46, constituting $5 \%$ of the total project costs, mandatory equity contribution of Varna Municipality,

- BGN 563,898.26 - additional equity contribution of Varna Municipality.

\subsection{Revitalization of public spaces in Poznan (Poland)}

The Interactive Cathedral Island Heritage Center of Poznań - the Porta Posnania project (ICHOT Brama Poznania) was implemented as a part of the "Royal-Imperial Route of Poznań" ("Trakt Królewsko-Cesarski w Poznaniu") program and the third edition of the Municipal Program for the Revitalization of Poznań. It was co-financed under Measure 6.4 of the Operational Program Innovative Economy 2007-2013 - "Investments in tourism products of supra-regional importance"1. Total project cost was PLN 98,900,000.00 with a financing level of $60 \%$, which amounted to 59,340,000.00 PLN (85\% ERDF - PLN 50,439,000.00, 15\% state budget - PLN 8,901,000.00) (http://bramapoznania.pl/o-projekcie/).

The project was implemented in the Cathedral Island (Ostrów Tumski) in the Środka District, which is the oldest and most historically and culturally valued part of Poznan. The Interactive Cathedral Island Heritage Centre was built on the bank of Cybina river, in place of a former lock which was once a part of a 19th century Prussian fortification system. ICHOT Porta Posnania is situated both on the side of Śródka (the new building) and Cathedral Island, where the restored historic building has been adapted for purposes of tourism (Poznań Municipal Revitalization Program, Edition 3, p. 40). The implementation phase started in the first quarter of 2009 with completion planned for mid-2012. However, after a delay of close to 2 years, the Center was commissioned on 30 April, 2014.

The main goal for the construction of the Interactive Heritage Center was the development of tourism in Cathedral Island and Śródka, as the oldest parts of Poznan, closely tied to the history of the city and the whole country. The outcome is a quality product of cultural tourism, which, thanks to its modern display of cultural heritage, helps to increase the tourism competiveness and appeal of

${ }^{1}$ Information on ICHOT-Porta Posnania project was obtained from KILJAŃSKA (2014). 
Poznań and the Wielkopolska region, on local, regional, state and international levels. Functional effects of the project include complimentary investment in cultural tourism and accompanying services, which should have a positive effect on social and economic development of this area and the city of Poznań (Project Feasibility Study for the project under Measure 6.4 of the Operational Program Innovative Economy 2007-2013 “Investments in tourism products of supra-regional importance" "The Interactive Cathedral Island Heritage Center of Poznań, the Cradle of Statehood and Christianity in Poland" 2010, p. 25).

The following are detailed objectives of the project:

- creation of a competitive and innovative tourism product in Poznan, of a unique and supraregional character, helping to highlight the role and importance of Cathedral Island in the culture and history of the whole nation,

- growth of tourism traffic in Poznań and the entire Wielkopolska region, due to improvements in tourism infrastructure and accompanying services,

- fostering of national heritage and patriotic attitude through social education,

- growth in city appeal as a host of sports events organized as part of the UEFA Euro 2012 Championships.

The last objective was not met, due to the afore-mentioned two-year delay during the project implementation stage (Project Feasibility Study for project under Measure 6.4 of the Operational Program Innovative Economy 2007-2013 "Investments in tourism products of supra-regional importance" - "The Interactive Cathedral Island Heritage Center of Poznan, the Cradle of Statehood and Christianity in Poland" 2010, p.25).

The investment is one of the main attractions of the Royal-Imperial Route, itself a product of cultural tourism, clustering the key attractions of Poznań. Supplementary activities included the construction of a coach parking at Bydgoska Street, enhancements such as street furniture and green areas, restoration and extension to Gdańska Street, construction of a pedestrian zone between the ICHOT building and the Bishop Jordan Bridge and improvements to the tourist information system. The ICHOT Center - Porta Posnania is an introduction and the invitation to visit the historical and cultural sites of Poznań.

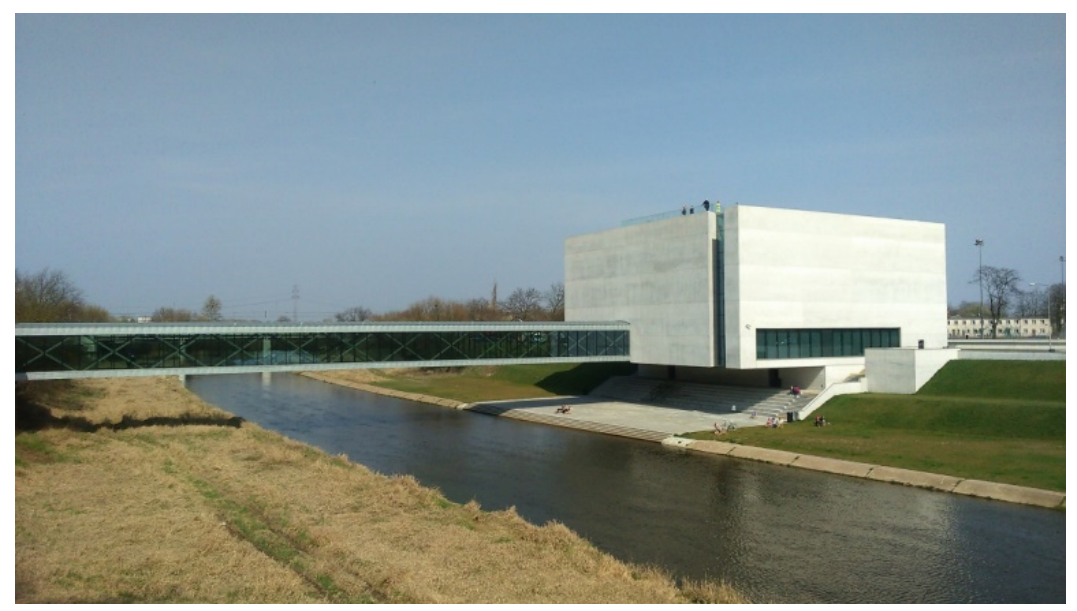

Fig. 2. ICHOT - Porta Posnania. Source: own colection.

As the result of implementing the project, the quality and innovation of cultural tourism services in the Wielkopolska capital have increased. Additionally, improvements in the spatial domain have been achieved and the tourism function of Cathedral Island and Śródka has been resumed and consolidated, which has facilitated the process of their revitalization. It is possible to find symptoms of the conscious construction of a network of culture sites - ICHOT-Porta Posnania, the Archeological Reserve Genius Loci and the Archdiocesan Museum. Such consolidation of the cultural offer channels the tourists' attention into the areas of Śródka, Cathedral Island and nearby Chwaliszew, creating a link with the not-too-distant Old Market Square in Poznań.

\section{Discussion and Conclusions}

Urban public space should be open and accessible, creating an interesting, unique and aesthetically 
and functionally attractive offer. Urban living space must be likeable and pleasant in order to effectively attract people. It must not be detached from its environment, but instead linked to it, ensuring continuity and connectivity.

The positive and encouraging revitalization activities of the local governments of Varna (Bulgaria) and Poznan (Poland) discussed in the article, indicate that the management of investment projects in the countries of Central-Eastern Europe is integrated with local development objectives. Such perception of the role of local governments carries good prospects of success and determines livelihood of the initiatives themselves. It also provides a stimulus for the development of their surroundings and the city as a whole. Each case study presented an innovative and nationally competitive culture and tourism product. In a wider sense, such products lead to improvements in the city's appeal, and indirectly influence the quality of life in the city, as well as its general socioeconomic and spatial condition.

In both of the discussed cases, it was possible to improve the status and attractiveness of the urban environment in the downtown, encourage improvements in the environment in the spirit of balanced development, and create unique and supra-regional space, which highlights the role and significance of the cities in question. The development of the neighborhood and wider surroundings achieved the effects of improving the aesthetics and modernization of pedestrian zones and public recreation areas, creating an accessible architectural environment as well as conditions for the integration of various social groups, and increasing the safety and security of a previously unfriendly urban environment. Furthermore, the analyzed case studies highlight the necessary skills required for obtaining EU funds and their spending according to the set out objectives. EU resources have become a crucial component of investment budgets, enabling fundamental changes in public space.

\section{References}

BeLNIAK S., 2008, A Partnership of Public and Private Sectors as a Model for the Implementation of Urban Revitalization Projects, Journal Of European Real Estate Research, Vol. 1, No. 2.

BodnAR J., 2015, Reclaiming Public Space, Urban Studies, September 2015, Vol. 52, No. 12, pp. 20902104.

COLLET A., 2012, Montreuil, <<le 21e arrondissement de Paris >>? La gentrification ou la fabrication d'un quartier ancient de centre-ville, Actes de la recherché en Sciences Sociales, Centre-villes, modèles, lutes, pratiques, décembre 2012, 195, SEUIL, pp. 13-37.

CzORNIK M., 2004, Miasto: ekonomiczne aspekty funkcjonowania (City: Economic Aspects of Functioning), Prace Naukowe Akademii Ekonomicznej im. Karola Adamieckiego w Katowicach, Wydawnictwo Akademii Ekonomicznej w Katowicach, Katowice.

Jak przetworzyć Miejsce. Podręcznik kreowania udanych przestrzeni publicznych (How to Convert a Place. A Handbook on Successful Public Spaces Creation), http://www.sak.org.pl/data/file/jak_przetworzyc_miejsce_429.pdf (dostęp 05 maja 2015).

KILJAŃSKA P., 2014, Prognostyczna ocena efektywności spoteczno-ekonomicznej przedsięwzięć rewitalizacyjnych na przykładzie projektu ICHOT - Brama Poznania" (Prognostic Assestment of SocioEconomic Effectiveness of Revitalization Activities Based on ICHOT-Porta Posnania Project), praca dyplomowa (promotor - dissertation advisor - S. Palicki), mpm, Uniwersytet Ekonomiczny w Poznaniu.

PALICKI S., 2007, Rewitalizacja na tle innych przejawów odnowy miast (Revitalization as the One of the Aspects of Urban Renewal), Studia i Materiały Towarzystwa Naukowego Nieruchomości (Journal of the Polish Real Estate Scientific Society), Vol. 15, No. 1-2, pp. 189-198.

PoIeSI, F., CAVAllaro, A., 2015, Predicting and Recognizing Human Interactions in Public Spaces, Journal of Real-Time Image Processing, Volume: 10, Issue: 4, pp. 785-803.

IGN (Institute for Real Estate Management), Polityka mieszkaniowa miasta Poznania na lata 2012-2022 (Housing Policy of Poznan City for the period 2012-2022), Instytut Gospodarki Nieruchomościami, Katowice, 2012.

REKOWSKI M., 2011, Mikroekonomia (Microeconomics), Wydawnictwo Akademia, Poznań.

Sмith N., 1987, Gentrification and the Rent Gap, Annals of the Association of American Geographers, Vol. 77, Issue 3, pp. 462-478.

Contested Public Spaces, American Journal of Community Psychology, Vol.56, Issue: 3-4, pp. 368-382.

TROJANEK M., Strategic Municipal Real Estate Management, Journal of International Studies, Vol. 8, No. 2, 2015, pp. 9-17. 
TROJANEK M., 2014, Zmiany wptywów z nieruchomości w dochodach miasta Poznania w latach 2001-2012 (Changes in Revenues from Real Estates in Poznań City in the Period 2001-2013), Zarządzanie i Finanse. Journal of Management and Finance Vol. 12, No. 4/2014, ss. 457-469.

VAN CRIEKINGEN M., DECROLY J. M., 2003: Revisiting the Diversity of Gentrification: Neighbourhood Renewal Processes in Brussels and Montreal, Urban Studies, Vol. 40, No 12, 2451-2468.

WOJEWNIK-FILIPKOWSKA A., 2012, Inwestycje w procesie odnowy miast - koncepcja oceny efektywności projektów (Investments in the Process of Urban Regeneration - Concept of Assessing Project Effectivness), Studia i Materiały Towarzystwa Naukowego Nieruchomości (Journal of the Polish Real Estate Scientific Society), Vol. 20, No. 3, pp. 247-259.

ZHENG, S., KAHN, M. E., 2013, Does Government Investment in Local Public Goods Spur Gentrification? Evidence from Beijing, Real Estate Economics, Spring 2013, Vol. 41, Iss. 1, pp. 1-28.

ZIOBROWSKI Z., Rewitalizacja miast polskich - podsumowanie projektu (Polish Urban Revitalization Project Summary), I Kongres Rewitalizacji Miast Polskich, Kraków, 2010, http://www.sgh.waw.pl/katedry/kin/wydarzenia/poznan/projekt_irm.pdf (dostęp 15 września 2012).

ŹRÓBEK-RÓŻAŃSKA A., 2011, Uwarunkowania prawne gospodarki nieruchomościami w gminie w aspekcie kształtowania jej rozwoju (Legal Conditionings Concerning Real Estate Management in a Commune in View of its Development), Studia i Materiały Towarzystwa Naukowego Nieruchomości (Journal of the Polish Real Estate Scientific Society), Vol. 19, No. 2, pp. 39-48. 